\title{
Effects of Single and Sequential Defoliations on the Carbohydrate Reserves of Four Range Species
}

\author{
JOHN W. MENKE AND M.J. TRLICA
}

\begin{abstract}
Four range species, fourwing saltbush (Atriplex canescens), antelope bitterbrush (Purshia tridentata), scarlet globemallow (Sphaeralcea coccinea), and blue grama (Bouteloua gracilis) were defoliated heavily (removing 90\% of the foliage) at 1 of 5 phenological stages. In addition, other plants were clipped from 1 to 6 times at 3 phenological stages over a 2-year period. Total nonstructural carbohydrate (TNC) reserves of fourwing saltbush and antelope bitterbrush were most sensitive to a single defoliation at the seedshatter phenological stage. Blue grama was affected most at the rapid growth stage, whereas scarlet globemallow was not significantly affected by any of the single defoliations. A single defoliation proved adequate for determination of the most sensitive season for defoliation. Antelope bitterbrush was affected more by 6 successive intense defoliations than were the other 3 species: scarlet globemallow $<$ blue grama $<$ fourwing saltbush. TNC reserve cycles were severely dampened in antelope bitterbrush, and less so in fourwing saltbush.
\end{abstract}

A number of early studies on rangeland plants of the arid and semiarid western USA established that carbohydrate reserves were related to the intensity, frequency, or season of defoliation (Sampson and McCarty 1930, Graber 1931, Bukey and Weaver 1939, Hanson and Stoddart 1940, McCarty and Price 1942, and Mcllvanie 1942). Albertson et al. (1953) found that root weights of 2 shortgrass prairie range plants, including blue grama, were depressed by clipping close to the ground. Crider (1955) demonstrated that harvesting half or more of the foliage from a grass plant caused root growth to stop for 6 to 18 days, and removing $90 \%$ of the foliage stopped root growth for 17 days.

Blaisdell and Pechanec (1949) found that herbage removal is most injurious after the date when substantial regrowth is impossible and before maturity. De Bano (1957) showed that season of clipping affected the vigor of desert range plants more than did intensity of clipping. We initiated this study to provide information on the effect of season of defoliation on 4 range species, and document the timing and magnitude of the departure of the total nonstructural carbohydrate (TNC) cycle of heavily defoliated plants from those of control plants.

\section{Study Areas}

The study was carried out from 1970 through 1972 at 2 locations in northern Colorado. One location was the Central Plains Experimental Range (CPER) administered by the Agricultural Research Service, U.S. Department of Agriculture, about $50 \mathrm{~km}$ northeast of

\footnotetext{
Authors are associate professor of range ecology, Department of Agronomy and Range Science, University of California, Davis 95616; and associate professor of range science, Range Science Department, Colorado State University, Fort Collins 80523. At the time of this research the senior author was graduate research assistant, Department of Range Science, Colorado State University, Fort Collins.

This research was supported by the Bureau of Land Management and Colorado State University Experiment Station through Project 100 (Scientific Series Paper No. 2488).

Manuscript received September 28, 1979.
}

Fort Collins. The second location, about $6 \mathrm{~km}$ west of Maybell, Colo., was on land administered by the Bureau of Land Management, U.S. Department of Interior. The CPER location is typical of the shortgrass type of the Central Great Plains region. The Maybell location, in the intermountain sandhills region of western Colorado, is a shrubland locally dominated by antelope bitterbrush (Purshia tridentata), although big sagebrush (Artemsia tridentata) is the dominant shrub in many of the lowland drainages. The climate and soils of the 2 study areas have been described (Trlica et al. 1977).

\section{Methods and Procedures}

Three 0.4-ha exclosu res were constructed at each study location in the summer of 1970. Plants within exclosures were either defoliated at a $90 \%$ intensity of foliage removal at 1 of 5 phenological stages, or were given 1 to 6 sequential defoliation at 3 phenological stages over a 2-year period. Fourwing saltbush (Atriplex canescens), scarlet globemallow (Sphaeralcea coccinea), and blue grama (Bouteloua gracilis) were studied at the CPER location, whereas, antelope bitterbrush was studied at the Maybell location.

Three plants each of fourwing saltbush and antelope bitterbrush within each exclosure were clipped under each treatment. Blue grama and scarlet globemallow within $2,1.0-\mathrm{m}^{2}$ plots were clipped in each exclosure. Plants clipped once at one of the 5 phenological stages from the fall of 1970 through the late summer of 1971 were evaluated for TNC reserves in the fall of 1971. This single defoliation experiment was repeated in 1971-72. Under the single defoliation treatments, fourwing saltbush, scarlet globemallow, and blue grama were clipped during the phenological stages of quiescence (November 5-20), early growth (April 15-20), rapid growth (June 1-10), near-maturity (August 1-15), and seed shatter (late seed shatter for scarlet globemallow (September 1-15). Antelope bitterbrush plants were clipped during quiescence (November 5-20), early growth (April 15-20), fruit development (June 1-10), seed shatter (August 1-15), and fall regrowth (September 1-15).

In the sequential defoliation experiment plants were clipped from the fall of 1970 through the late summer of 1972 . Unlike the single defoliation experiment, plants were clipped at quiescence, rapid growth, and seed shatter over both years for fourwing saltbush; quiescence, fruit developing, and fall regrowth for antelope bitterbrush; quiescence, rapid growth, and late seed shatter for scarlet globemallow; and quiescence, rapid growth, and regrowth or seed-shatter stages for blue grama. Some plants were evaluated for TNC reserves at the time of each defoliation so that cumulative effects of clippings could be determined. Additional plants that had undergone all 6 defoliations were evaluated for TNC reserves in the fall of 1972, making a total of 7 evaluations.

Plants were excavated by digging around their perimeter to a depth of $30 \mathrm{~cm}$. Plants and soil were then removed together, and the soil was carefully removed by hand-shaking and washing with cold water. TNC levels were determined in both tap roots and live 


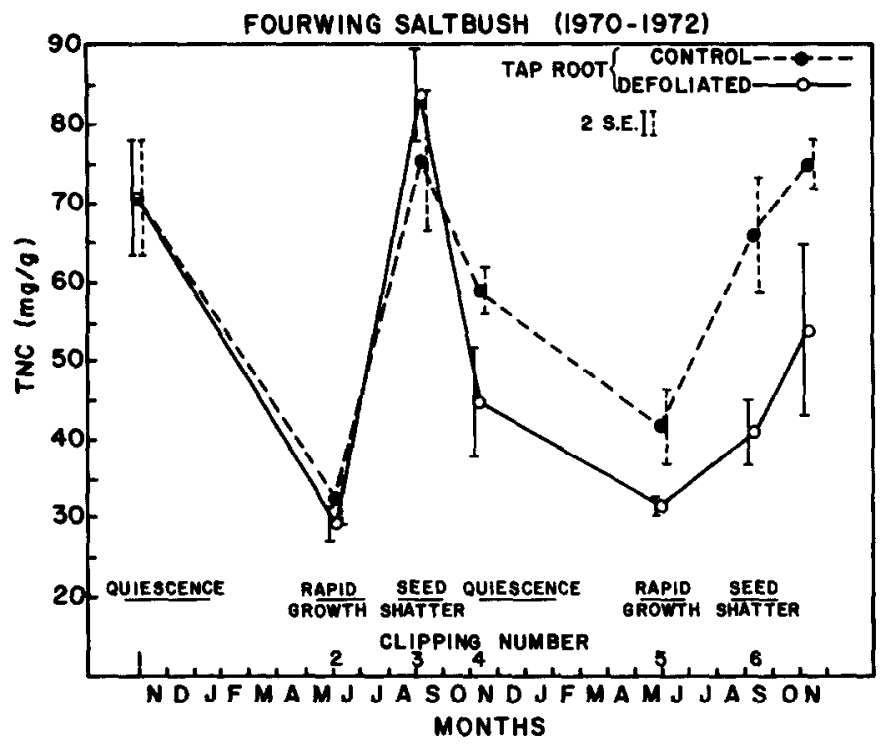

Fig. 1. Average total nonstructural carbohydrates (TNC) in tap roots of control and successively defoliated fourwing saltbush plants.

basal stems $(0.5$ to $1.0 \mathrm{~cm}$ diameter) of fourwing saltbush and antelope bitterbrush. For scarlet globemallow and blue grama, roots and crowns were used to determine TNC levels. Rhizomes were included with the root samples of scarlet globemallow. Total nonstructural carbohydrates were extracted from a $0.5-\mathrm{g}$ plant sample with $0.2 \mathrm{~N}$ sulfuric acid (Smith et al. 1964), and TNC levels were determined on a glucose equivalent basis (Heinze and Murneek 1940).

All data were analyzed by standard analysis of variance techniques (Steel and Torric 1960). Duncan's multiple range test was used to separate means $(p<0.05$ and 0.10$)$.

\section{Results and Discussion}

\section{Fourwing Saltbush}

Tap root and basal stem TNC levels of fourwing saltbush were affected very little by a single clipping, except at the seed shatter stage. Only the $42 \mathrm{mg} / \mathrm{g}$ basal stem TNC level in the fall of 1972 was depressed $(p<0.10)$ below the $52 \mathrm{mg} / \mathrm{g}$ in control plants. Plants defoliated at seed shatter and control plants had 41 and $54 \mathrm{mg} / \mathrm{g}$ in basal stems, respectively, the first year, and tap root TNC levels

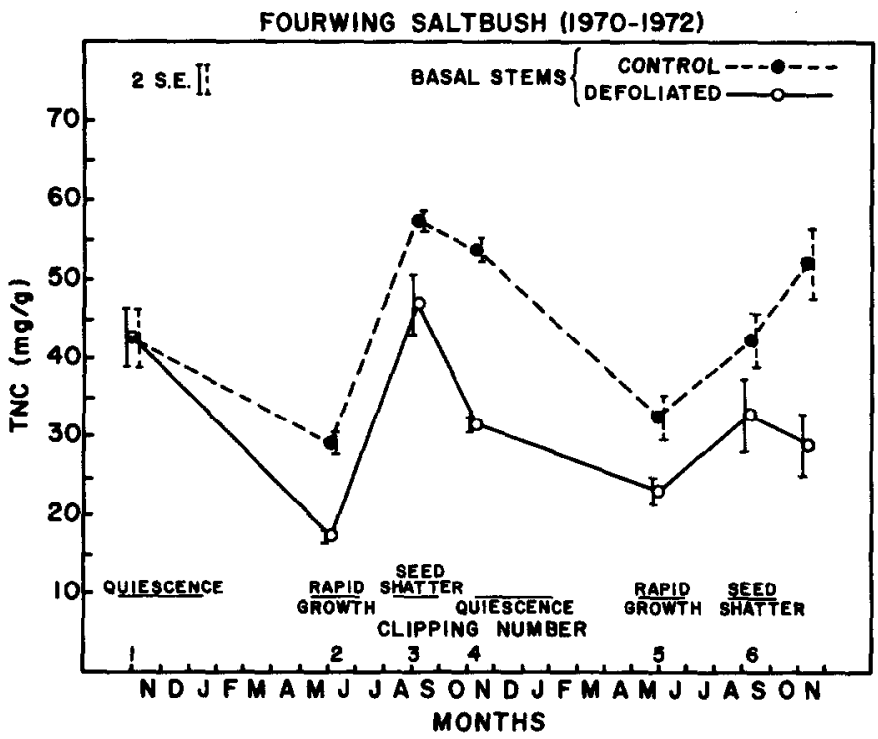

Fig. 2. Average total nonstructural carbohydrates (TNC) in basal stems of control and successively defoliated fourwing saltbush plants.

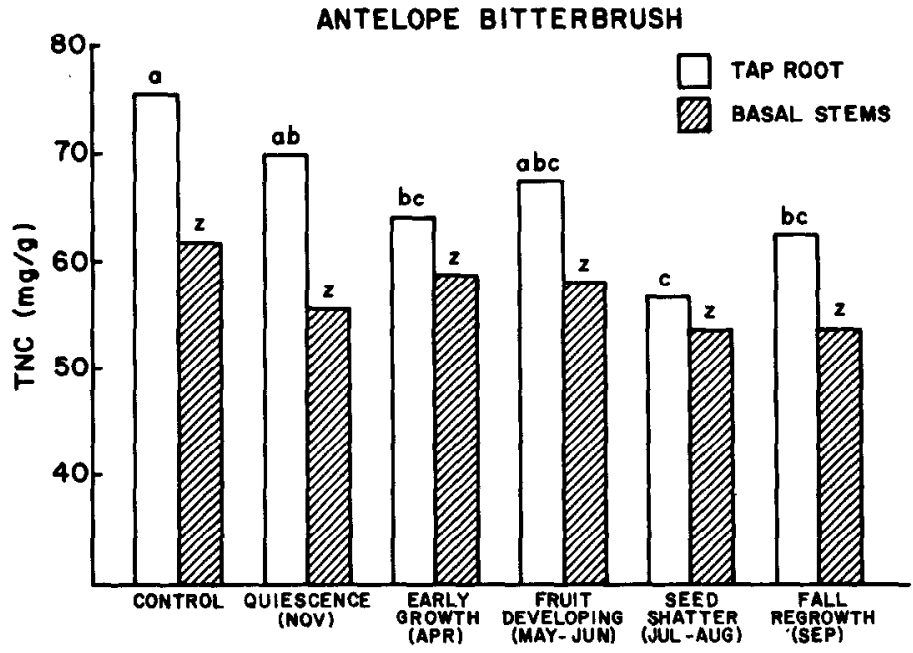

DEFOLIATION TREATMENTS BY PHENOLOGICAL STAGE

Fig. 3. Average total nonstructural carbohydrates (TNC) in fall 1971 and 1972 for tap roots and basal stems of control antelope bitterbrush plants and plants defoliated once at 5 different phenologicalstages. Tap root or basal stem TNC levels labeled with the same letter are not significantly different $(\mathrm{p}<.05)$.

were also lower but not significantly lower.

Tap root TNC levels of sequentially defoliated fourwing saltbush plants were not depressed below those of control plants until after the third clipping (Fig. 1), whereafter their reserve status remained significantly lower than unclipped plants. The first seed shatter clipping caused the initial divergence of the tap root TNC cycle.

Basal stem TNC levels were depressed earlier than tap root TNC levels, and clipping at the seed shatter stage, again, caused the greatest divergence between clipped and control plant TNC cycles (Fig. 2). After the third clipping the basal stem TNC cycle for clipped plants remained somewhat dampened. In the fall, after 6 clippings, basal stem reserve levels were $44 \%$ lower in clipped than in control plants. The more concentrated tap root reserves were depressed $28 \%$ at the fall analysis after 6 clippings. Trlica and Cook (1971) reported that TNC reserves of 2 desert Atriplex species in Utah were also reduced most when plants were clipped late in the growing season.

\section{Antelope Bitterbrush}

Levels of TNC in tap roots of antelope bitterbrush were most depressed $(p<0.05)$ by a single clipping at early growth, seed shatter or fall regrowth stages (Fig. 3). Only the seed shatter clipping resulted in depressed TNC reserves below those of control plants both years, and then only for tap roots. No significant differences were detected for basal stems.

Tap root TNC cycles of control and defoliated plants diverged most after each fall regrowth clipping in the sequential defoliation experiment (Fig. 4). Recovery was less complete after the second year of 3 clippings when fall analysis showed clipped plants had TNC levels $23 \%$ lower than control plants. It appeared that the late-season clipping severely reduced root storage but the antelope bitterbrush was adapted to intense defoliation. Analysis of the basal stem response, however, showed that the whole-plant carbohydrate balance was not being maintained as well as was indicated by the tap root TNC status alone.

Basal stem TNC levels were severely depressed by 6 sequential defoliations (Fig. 5). The greatest divergence between control and defoliated plants occurred after each defoliation at the fruit developing stage, and thereafter during the normal storage portion of the annual TNC cycle (Menke and Trlica 1981). Using fall TNC status as a criterion, basal stem TNC levels were $21 \%$ lower than in control plants after 3 clippings and 53\% lower after 6 clippings. Little if any basal stem TNC storage was detected after the fifth 


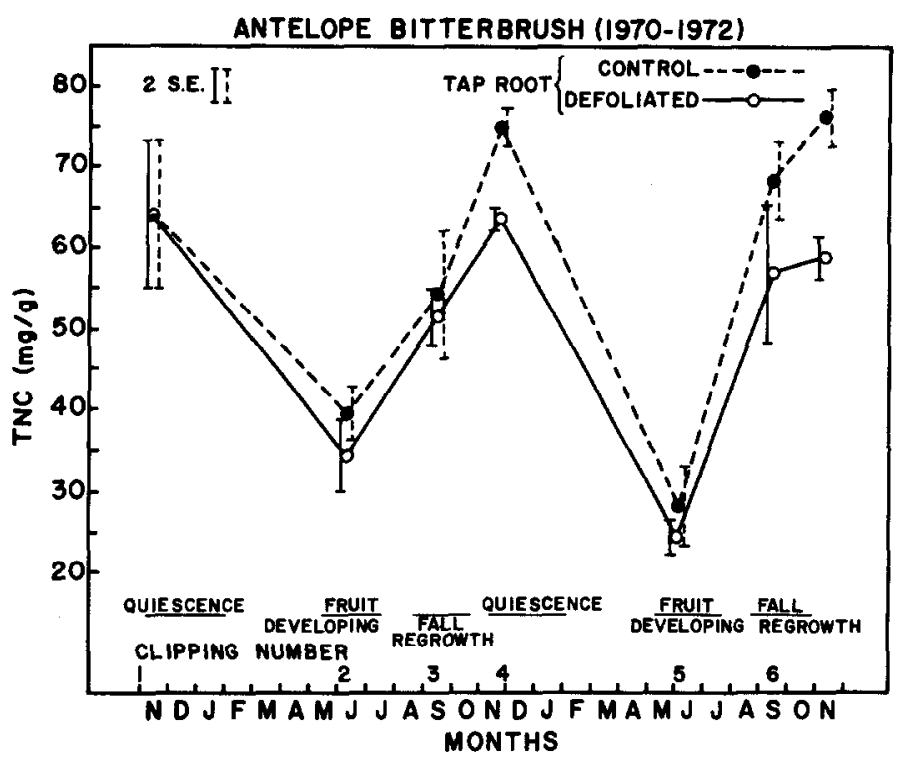

Fig. 4. Average total nonstructural carbohydrates (TNC) in tap roots of control and successively defoliated antelope bitterbrush plants.

defoliation, and the TNC cycle was severely dampened.

Many decadent bitterbrush plants with a high percentage of dead stems and abundant crown sprouting were observed at the Maybell location, an area that had been grazed heavily by sheep over the past decade. It appeared that root reserves may not be readily mobilized to maintain aboveground stem reserves. Basal stem reserves appeared to be approaching a critical level after several severe defoliations, whereas tap root reserves were not affected severely. Given that antelope bitterbrush has low seedling survival in sandy soil, its adaptation for stand maintenance in the Maybell area appears to be fostered by a sacrifice of older woody top growth followed by crown sprouting below stiff dead stems, making new growth relatively unavailable to large grazing animals.

\section{Scarlet Globemallow}

No significant differences in TNC reserve levels were observed among control scarlet globemallow plants and plants clipped once at 1 of 5 phenological stages. Scarlet globemallow has relatively little shoot exposed in comparison with its extensive root and rhizome system, which might partially explain its high tolerance to intense defoliation. Trlica et al. (1977) showed that any depression

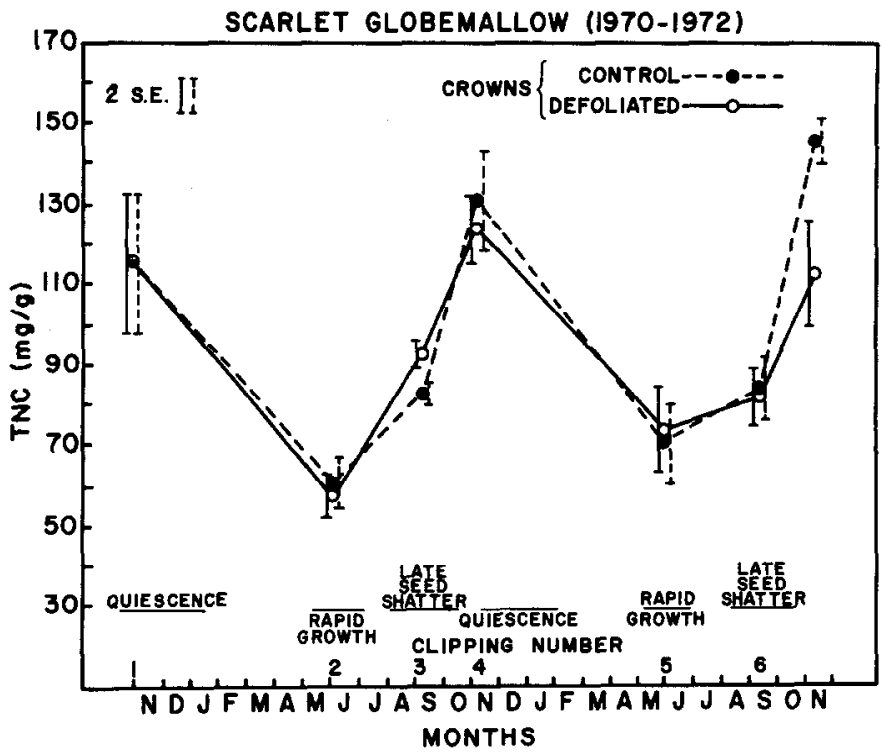

Fig. 6. Average total nonstructural carbohydrates (TNC) in crowns of control and successively defoliated scarlet globemallow plants.

in TNC reserve storage for this species was recovered after as little as 14 months of rest.

Root TNC reserve levels remained unaffected throughout the 6 sequential defoliations, and crown TNC reserve levels of defoliated plants were significantly lower $(p<0.05)$ than in control plants only after all 6 defoliations (Fig. 6). Both root and crown TNC concentrations cycled between about 60 and $160 \mathrm{mg} / \mathrm{g}$, which is a very high level of reserve storage. A number of investigators have associated survival under unfavorable environmental conditions with a capacity to store ca rbohydrates (Hanson and Stoddart 1940, McCarty and Price 1942, Wilson 1944, Smith 1964, Mooney and Billings 1965).

\section{Blue Grama}

When root and crown TNC reserve levels were each averaged over the 2 years of the single defoliation study, there were no significant $(p>0.10)$ differences between control blue grama plants and plants defoliated once at 1 of the 5 phenological stages (Fig. 7). In the relatively wet year of 1972 , however, plants clipped at rapid growth or seed shatter had lower $(p<0.10)$ crown TNC levels than control plants. Fall herbage yields for plants clipped at rapid

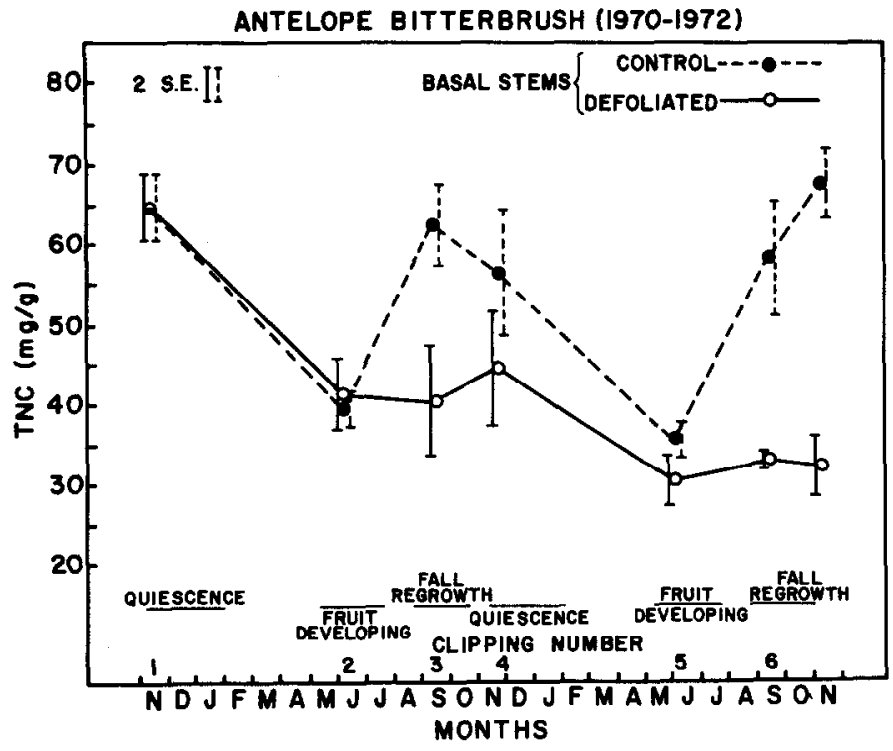

Fig. 5. Average total nonstructural carbohydrates (TNC) in basal stems of control and successively defoliated antelope bitterbrush plants.
BLUE GRAMA

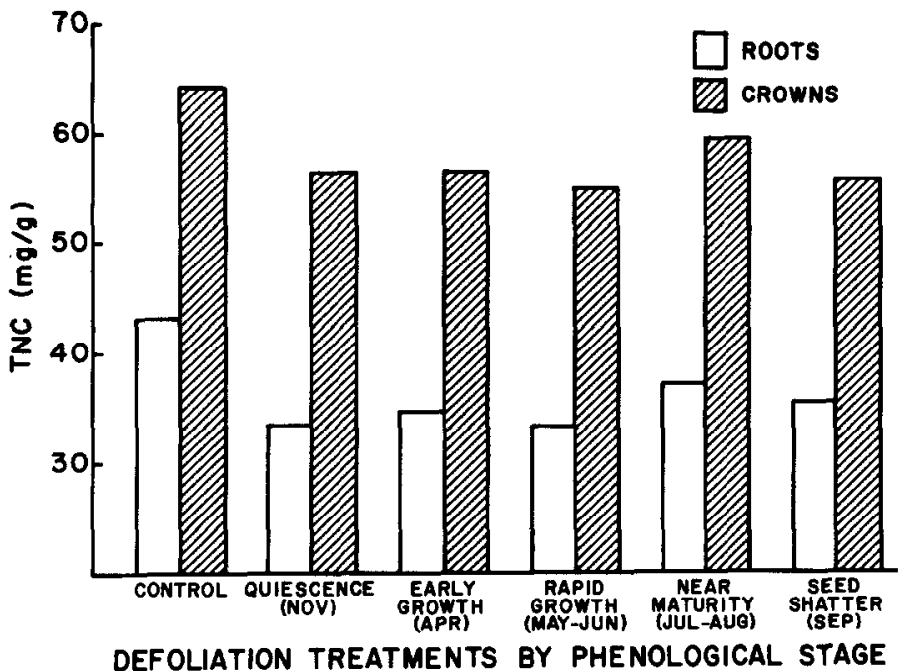

Fig. 7. Average total nonstructural carbohydrates (TNC) in fall 197I and 1972 for roots and crowns of control blue grama plants and plants defoliated once at 5 different phenological stages. 
Hanson, W.R., and L.A. Stoddart. 1940. Effects of grazing upon bunch wheat grass. J. Amer. Soc. Agron. 32:278-289.

Heinze, P.H., and A.E. Murneek. 1940. Comparative accuracy and efficiency in determination of carbohydrates in plant material. Missouri Agr. Exp. Sta. Res. Bull. 314.

Kinsinger, F.E., and H.H. Hopkins. 1961. Carbohydrate content of underground parts of grasses as affected by clipping. J. Range Manage. 14:9-12.

MeCarty, E.C., and R. Price. 1942. Growth and carbohydrate content of important mountain forage plants in central Utah as affected by clipping and grazing. USDA Tech. Bull. 818 .

Mcllvanie, S.K. 1942. Carbohydrate and nitrogen trends in blue bunch wheatgrass, Agropyron spicatum, with special reference to grazing influences. Plant Physiol. 17:540-557.

Menke, J.W. 1973. Effects of defoliation on carbohydrate reserves, vigor, and herbage yield for several important Colorado range species. Ph.D. Diss., Colorado State Univ., Fort Collins.
Menke, J.W., and M.J. Trlica. 1981. Carbohydrate reserve, phenology, and growth cycles of nine Colorado range species. J. Range Manage. 34:269277.

Mooney, H.A., and W.D. Billings. 1965. Effects of altitude on carbohydrate content of mountain plants. Ecology 46:750-751.

Sampson, A.W., and E.C. McCarty. 1930. The carbohydrate metabolism of Stipa pulchra. Hilgarida 5:61-100.

Smith, D. 1964. Winter injury and the survival of forage plants. A review. Herb. Abstr. 34:203-209.

Smith, D., G.M. Paulsen, and C.A. Raguse. 1964. Extraction of total available carbohydrates from grass and legume tissue. Plant Physiol. 39:960-962.

Steel, R.G.D., and J.H. Torrie. 1960. Principles and Proced ures of Statistics. McGraw-Hill Book Co., New York.

Trlica, M.J., and C.W. Cook. 1971. Defoliation effects on carbohydrate reserves of desert species. J. Range Manage. 24:418-425.

Trlica, M.J., M. Buwai, and J.W. Menke. 1977. Effects of rest following defoliations on the recovery of several range species. J. Range Manage. 30:21-27.

Wilson, H.K. 1944. Control of noxious plants. Bot. Rev. 10:279-326.

\section{POSITION ANNOUNCEMENT Department of Animal and Range Sciences South Dakota State University Brookings, South Dakota}

Title:

Assistant in Range Science

Location:

Dept. of Animal \&

Range Sciences

South Dakota State University

Box 2170

Brookings, South Dakota 57007

Effective Date:

Applications will be accepted until March 15, 1983, or until a suitable applicant has been selected, with employment beginning May 1 or as soon as possible thereafter.

\section{Qualifications:}

B.S. or M.S. in Range Science or related field. Preference will be given for education and experience in range science or closely related disciplines. Assistant must be completely reliable and have an appreciation for and a desire to be involved in range research. Experience in field data collection and data processing is desirable. The position should be considered as providing valuable experience for individuals contemplating future graduate study.

\section{Responsibilities:}

The research assistant is directly responsible to the range science project leader and will work closely with him in all phases of his research. Duties include (1) coordination of field research activities and needs with the Super- intendent of the Cottonwood Range and Livestock Research Station or other research stations where research is being conducted; (2) employment and supervision of summer employees; (3) development of research plants with project leader; (4) planning and scheduling field sampling; (5) assisting in selection of research cooperators and establishment of field studies; (6) maintenance and care of field and laboratory equipment; (7) careful and sometimes detailed measurements of range ecosystem components, including vegetation, soil and grazing animals; (8) coordination of laboratory processing of samples and computerization of data with range lab technician; and (9) assisting with data processing, data analyses and preparation of publications. Oral presentations may be required occasionally.

The assistant will be stationed at the Range and Livestock Research Station during the field season and the remainder of the year in Brookings.

Application:

Interested persons should submit a resume, university transcripts and three letters of recommendation to: Professor James K. Lewis, Department of Animal and Range Sciences, South Dakota State University, Box 2170, Brookings, South Dakota • 57007-0392 • Telephone 605688-5165

South Dakota State University is an Affirmative Action/Equal Opportunity Employer (Male/Female). 